\title{
ІДЕЯ ДЕРЖАВНОСТІ ЯК КОНЦЕПТУАЛЬНА ЗАСАДА ПУБЛІЦИТИКИ ДМИТРА ДОНЦОВА
}

\author{
Вікторія Колкутіна \\ Національний університет «Одеська юридична академія» \\ вул. Фонтанська дорога, 23, 65009, Одеса, Україна \\ e-mail: kolkutinav@ukr.net \\ https://orcid.org/0000-0002-3823-8415
}

У статті досліджується ідея державності як концептуальна засада публіцистики Дмитра Донцова. З’ясовано, що світоглядні акценти Д. Донцова базувалися на патріотизмі, активній національній свідомості та імперативі державної самостійності. В основу консолідації нації дослідник покладав природний процес еволюціонування національної самосвідомості індивідуума.

Ключові слова: Дмитро Донцов, ідея державності, національна ідея, публіцистика, українські письменники-класики.

Постановка проблеми. В історії української публіцистики ХХ століття помітно вирізняється творчість видатного політичного філософа, громадсько-політичного діяча, публіциста, есеїста, редактора, видавця, літературного критика, ідеолога вольового націоналізму Дмитра Донцова (1883-1973). За роллю, котру відіграв цей мислитель як протагоніст в історії української культури й характером ідейного світу, його не випадково порівнюють з італійцями Джузеппе Мадзіні та Паскуале Манчіні, іспанцями Мігелем де Унамуно та Хосе Ортегою-і-Гассетом, англійцями Гілбертом Кійтом Честертоном та Томасом Стернзом Еліотом, німцями Йоганном Фіхте та Освальдом Шпенглером, французами Морісом Барре та Шарлем Морра тощо.

Творчості Д. Донцова присвячено значну кількість різних за обсягом, світоглядною заангажованістю та науковою спрямованістю праць авторства С. Андрусів, В. Артюха, О. Багана, В. Бондаренка, М. Васьківа, Г. Грабовича, Я. Дашкевича, Р. Сндика, І.Загребельного, В. Іванишина, П. Іванишина, М. Ільницького, І. Качуровського, С. Квіта, I. Руснак, Т. Салиги, Г. Сварник, Л. Сеника, М. Сосновського, А. Стебельської, Ю. Шаповала, Т. Шептицької, Ю. Шереха та інших, де ідея держдавності як концептуальна засада публіицистики Д. Донцова розглядалася прямо чи побіжно крізь призму його філософських, культурологічних, політологічних, літературознавчих поглядів, проте в контексті осмислення націоцентричної сутності та багатогранності літературно-герменевтичного мислення переважно залишилася поза увагою дослідників.

(C) Колкутіна В., 2019 
Аналіз останніх досліджень і публікацій. У дусі інших ідеологів українського націоналізму (Т. Шевченка, І. Франка, М. Міхновського, Ю. Вассияна, О. Ольжича, С. Бандери, С. Ленкавського, Я. Стецька, В. Іванишина та ін.) філософське осмислення національної ідеї у Д. Донцова узгоджувалось вирішенням актуальних проблем нації з культурною традицією, історичним досвідом народу. Тому національна ідея у вольовому націоналізмі як «ідея державної самостійності» продовжувала шевченківську традицію націософського осмислення національної держави як «своєї хати»: «Вона стала аксіомою нашого думання, першою вимогою політики, черговим завданням дня. Була ця ідея нічим іншим, як парафразою Шевченкової «своєї сили у своїй хаті». Щоб нація була суверенна, щоб їй належала зверхність на нашій землі, щоб ніхто, ніякий чужинець не мав сили на тій землі» [1, с. 87]. Основними елементами національної ідеї, окрім іншого, стають «суверенність» у політиці, «вільна від держави Церква» у релігії, «окциденталізм» в культурі, «вільна ініціатива й зростання» в економічному житті [2, с. 117].

Антиколоніальна націоцентрична позиція публіциста знайшла своє продовження в постколоніалістичних працях сучасних літературознавців (П. Іванишина, Г. Клочека, О. Багана, В. Дончика, М. Жулинського, С. Андрусів, С. Квіта та ін.). Зупиняючись на ідеї національної самототожності, дослідники вказують на феномен денаціоналізації, вивчають процес духовної деградації, зупиняються на ролі поетів-державників.

Мета статті - на матеріалі літературно-критичних розвідок «Поетка українського Рісорджіменту (Леся Українка)», «Леся Українка» виокремити ідею державності як концептуальну засаду публіцистики Дмитра Донцова шляхом осмислення суті української національної ідеї у проекції до світогляду мислителя.

Завдання нашої розвідки - розкрити сутність поняття українська національна ідея як стрижень і основу ідеї державності в публіцистиці Д. Донцова, обгрунтувати найвиразніші і найзмістовніші ідеї у лесезнавчих студіях мислителя, оприлюднити концепцію державницької літератури в його рецепції.

Виклад основного матеріалу дослідження. Феномен Д. Донцова перебуває на межі різнопланових сфер суспільного буття й творчої діяльності - історії, літератури, політики передусім тому, що усі ці сфери об’єднує українська ідея. Епоха, у яку він жив і творив, характеризувалася формуванням нового світогляду, серцевиною якого була національна ідея. Д. Донцов стояв біля витоків творення філософії української ідеї [3; 4; 5], якій бракує «цілком нового духу. Бо що є нація, коли не скупчення мільйонів воль довкола спільного ідеалу? Ідеалу панування певної етнічної групи над територією, яку вона одержала в спадщину по батьках і яку хоче залишити своїм дітям» [6].

Українська ідея повинна постати як результат рефлексії національної самосвідомості та розв'язати питання буття, самовизначення й самореалізації нації: «...змагання до найвищої форми самоозначення нації, щоби ціла нація могла в повнім об’ємі виступити як самостійний, ні від кого не залежний чинник» [7, с. 56]. Ще в епоху романтизму - наприкінці XVIII - у першій половині XIX ст. - в Україні розпочалися спроби філософської рефлексії над національною ідеєю. Насамперед це помітно в публіцистиці та художній літературі, тобто в усіх видах словесної культури, в яких національна самосвідомість ставить собі смисложиттєві питання, що зачіпають не лише інтелект, а є питаннями реального буття окремої людини, національної чи етнічної спільноти. 
Українська національна ідея в історіографічній рецепції дослідника є рефлексійним віддзеркаленням симбіозу його інтересів у політичній, соціальній, духовно-культурній сферах. Ї̈ї системне, комплексне сприйняття залежить як від біографічних обставин, що впродовж тривалого часу формували ідейно-світоглядні переконання Д. Донцова, так і від смислових та ціннісно-цільових пріоритетів життєдіяльності українців у складний, помежовий період становлення нації. Такий комплекс ускладнюється станом західноукраїнського міжвоєнного суспільства, ідейно-настроєва парадигма якого була дотичною до національних зрушень у Західній Свропі наприкінці XIX - на початку XX століття. Не можна не враховувати й суспільно-політичну ситуацію, історичні умови розвитку України, які впливали як на інтелектуальний світ, так і на становлення національної ідеї.

У розбудові історичного виміру ідейно-естетичної концепції Д. Донцов спирався на романтичне розуміння духовної квінтесенції як головного вияву національної ідеї, культури українства, його самодостатності та самовдосконалення. Дослідник розширював функціональні завдання цієї культури, розумів творчу й громадську діяльність як націотворчу («Криза нашої літератури», «Роздвоєні душі», «Естетика декадансу», «Два табори»). Він сформував громадсько-політичні та історіософські складники націотворення на основі національної самосвідомості і ментальних особливостей.

Єдина національна дія скеровує народ на протидію чужоземцям та об’єднує розпорошені народні елементи в державну соборність. Ідеї мислителя у своїй основі були пронизані історизмом та традиціоналізмом, згідно з яким народові потрібно було повернути все, чого його позбавили, - етнонаціональну ідентичність, політичні права й незалежність. Ідейно-світоглядним орієнтиром для дослідника стала романтична постать Т. Шевченка, котрий здійснив світоглядний переворот, вибудовуючи історіософію як імператив художнього мислення. Д. Донцов виокремив у філософії Т. Шевченка націотворчий стрижень, потрактувавши національну ідею поета як стратегему, як консолідуючий і єдино можливий чинник існування нації. Вибудовуючи струнку історіософську концепцію власного розуміння призначення України, ії минулого й майбутнього, Д. Донцов розгорнуто репрезентував порушене Т. Шевченком екзистенційне для нації питання: бути чи не бути? («Пам’яті великого вигнанця», «В мартівську річницю»). Воно безпосередньо стосувалося не так фізичного існування нації, як іiі духовного відродження.

У публіцистиці ще раннього періоду Д. Донцов розширив функціональні межі духовної культури й ідентифікував творчу й громадську діяльність як націотворчу. Пошуки способів прояву ідейно-моральних засобів, які б сприяли самоствердженню нації та виокремленню основних складників національної ідеї в історичному розрізі привели мислителя до інтерпретації творчості Лесі Українки. Суттєвими проявами національної ідеї, що сприяють зрушенню й трансформації національного самовизначення, виступають романтично окреслені змістовні лінії «катастрофи», «великого визволення» [8, с. 163], «акціï», «virtus» $[8$, с. 156], «безкомпромісності» $[8$, с. 164165], «тріумфуючого ідеалізму» [8, с. 166], «ризику» [8, с. 169], «безсмертності волі» «вічного руху» [8, с. 171], естетичних засад епохи Середньовіччя.

Серед найвиразніших і найзмістовніших ідей у лесезнавчих студіях Д. Донцовим яскраво висвітлена ідея катастрофи, яка у віршах поетеси забарвлена у тривожний червоний колір, що свідчить про словесно-колірне мовомислення Лесі Українки 
(«Поетка українського Рисорджименто (Леся Украӥнка)»). Не вказуючи на заголовок поезій «Грішниця», «Товаришці на спомин», «Ангел помсти», публіцист цитує їх і найбільше розкриває образи «кривавого дня народження нації», «крові, яка освічує всяку ідею»: «...Як невідступна ідея вічно переслідує ï образ кривавого дня народження нації, коли, от як “під час породу, звісно, ллється кров і рветься крик...". Ба, навіть у того ангела, що з'являвся ï̈ фантазії, бачила вона, як "на білих крилах червоніла кров"» $[8$, с. 153]. У такому контексті дослідник доречно виокремлює в поетичній творчості Лесі Українки образ крові, увиразнений епітетом «червоний». Цей образ символічний, бо передає два значення - стан епохи (тривожної, хаотичної, напруженої) та ознаку чорного (!) кольору. Д. Донцов репрезентував червоний колір у поезії Лесі Українки як аналог чорного, апокаліптично-смертельного, який вказує не просто на екзистенційний перехід від життя до смерті, а й на загрозу перемоги смерті.

Розвідка була написана в часи складних суспільно-політичних обставин, які сталися після поразки національно-визвольних змагань українського народу. Тому у творчій практиці Лесі Українки Д. Донцов наголошує на проблемах, дотичних до сучасного йому стану суспільства та порушує екзистенційне питання смерті людства в часи кризових епох. У такий спосіб формується літературно-філософська екзистенціальна парадигма есеїста, в основі якої екзистенціали (туга, смерть, самотність, відчуження, тривога) та ідеї «трагічного оптимізму» й «трагічного стоїцизму», пов’язані з втратою рідної землі та надій на відновлення української державності й позбавлення національної ідеї. Поетеса, на думку Д. Донцова, семантикою червоного як чорного перш за все застерігала від духовної смерті націю, тому і бачила навкруги лише «кров, кров і кров!» [8, с. 153].

За Д. Донцовим, визначити дороговказ для української нації, шлях до політичного та культурного самовизначення, далекого від «мовчання, сліз або дитячих мрій» без виразно окресленої національної ідеї неможливо, адже Україна запала у глибокий «летаргічний сон». Невдоволений пасивністю, інертністю, «приспаною» свідомістю українців, дослідник у ранній літературній публіцистиці більше звернувся до Лесі Українки як до будителя нації і представив романтично забарвлені поетесою образи: «перуна», що має розбудити «заспані серця», «зброї», що «жде бійця», слова, що «шипіло неначе свист гадючий», дороги, «де не ростуть ні квіти, ні терни» $[9$, с. 23 , 24]. Д. Донцов цитував небагато ранніх віршів Лесі Українки («Хвилина розпачу», «Ворогам»). Він фактично їх не назвав. Очевидно, автор розраховував на інтелектуального читача, який, як і Д. Донцов, щиро переймається ідеями поетеси. У її віршах досліднику імпонують «відвага розпачу, мука сорому за власну нікчемність, і спазматичні, невстримані докори оспалим нащадкам великої колись нації...» Крім того, стаття перенасичена образами, створеними художньою уявою самого Д. Донцова: українства, що «понуро брело» хибною дорогою; нації, яка то похована «живцем в домовину», то ніяк не пробудиться від «летаргічного сну» [9, с. 24].

У такому контексті в уяві Д. Донцова українство, нація - своєрідний збірний образ кожного пасивного українця, позбавленого національної ідеї. Це було свідченням того, що в ранній період дослідник тяжіє до художнього узагальнення, до вживання збірних образів, які дещо гіперболізовані, але й увиразнюють та чіткіше передають дух і настроєвість доби. Ці питання він продовжує розглядати у творчості Лесі Українки («Поетка українського Рисорджименто (Леся Українка)», «Леся 
Українка»), де акцентує на ідеї духовної витримки людини, необхідності вибору й прийняття рішення в часи національного зрушення, українського «Рисорджименто».

У такий спосіб Д. Донцов остаточно утверджує концепцію державницької літератури, згідно з якою «до основних ознак українського письменства належать: окциденталізм, що передбачав органічне засвоєння середньовічної настроєвості з її шляхетністю, аскетизмом, невгамовним поривом енергійного здобування; традиціоналізм, скерований на відродження героїчного українського минулого - ідеалів княжої доби й козаччини; романтизм, що спонукав до глибокого відчуття трагічності буття, але відкидав зневіру, стимулюючи оптимістичний погляд у майбутне (трагічний оптимізм Д. Донцова), та спрямовував життєву енергію людини на подолання приземленості, дріб'язковості, рутинності; волюнтаризм, що проголошував активне ставлення до будь-яких випробувань, негараздів, протиставляючи їм піднесення духовних сил особистості, iї вольові зусилля» [10, с. 8-9]. Цю концепцію можна означити як націєзберігаючу та націотворчу, адже вона виконувала місію порятунку загроженого існування українства, торувала шляхи до європейського визнання, порушувала філософські та морально-етичні проблеми поневоленого народу.

Процес націотворення в Україні витворився на грунті громадсько-політичних, історичних, суспільних, культурологічних та особистісних чинників, проте його конструктивними імпульсами були ментально-безвольна роздвоєна психологія українського руху та ідейна вичерпність і нежиттєздатність існуючих на той час політичних доктрин (лібералізм, соціалізм, націонал-демократизм тощо). Протистояти цим ментальним комплексам й ідеологічним стереотипам міг відновлювальний, регенеративний провід, що базувався на жертовному патріотизмові, відповідальності індивіда за долю нації, жертовності в ім'я волі й самостійності, піднесення інтересів загалу над власними, ірраціоналізмові, згуртованості навколо націєзахисної ідеї, спрямованої на державне самоутвердження в умовах виживання підневільної нації. Публіцист хоча й виражав ідейно-настоєві думки, постулати, тенденції своєї доби, але виходив із питомих українських реалій, потреб, вимог, запитів, сформував і показав шляхи націотворення і націєствердження, без яких нація не існуватиме і не виживатиме.

Висновки. Світоглядні акценти Д. Донцова як літературного публіциста щодо віддзеркалення української національної ідеї у творчості українських письменників базувалися на патріотизмові, активній національній свідомості та імперативові державної самостійності. В основу консолідації нації дослідник покладав природний процес еволюціонування національної самосвідомості індивідуума, у результаті чого той осягне високих щаблів саморозвитку і самовдосконалення. Духовна потреба людини передбачає тяжіння до активного життєствердження, руху, індивідуально-вольового покликання. Д. Донцов усвідомлював, що національна ідея виступає наріжним каменем, функціонально-інструментальним ресурсом, що сконденсував у собі природне прагнення окремої людини (народу в цілому) якомога повніше реалізувати закладений життєствердний, віталістичний потенціал. На наш погляд, у такий спосіб викристалізовувалася ідея державності як концептуальна засада публіцистики Дмитра Донцова. Цей аспект, гадаємо, знайде своїх вдумливих спостерігачів у майбутніх наукових працях. 


\section{REFERENCES}

1. Донцов Д. Демаскування шашелів // Донцов Д. Вибрані твори: у 10 т. / Редкол.: О. Баган (відп. ред.) і ін.; літ. ред. Я. Радевич-Винницький. Т.9: Ідеологічна і культурологічна есеїстика (1948-1957 рр.) / Упоряд., передм., комент. О. Баган. / Д. Донцов. Дрогобич: ВФ «Відродження», 2015. С. 81-101.

2. Донцов Д. Націоналізм // Донцов Д. Вибрані твори: у 10 т. / Редкол.: О. Баган (відп. ред.) і ін.; літ. ред. Я. Радевич-Винницький. Т.7: Ідеологічна та історіософська есеїстика (1923-1939 рр.) / Упоряд., передм., комент. О. Баган. / Д. Донцов. Дрогобич: ВФ «Відродження», 2014. С. 19-179.

3. Забужко О. Філософія української ідеї та європейський контекст / О. Забужко. Київ: Основи, 1993. 126 с.

4. Шморгун О. Основний зміст поняття «українська національна ідея» / О. Шморгун // Розбудова держави. 6 червня 1997. С. 10-19.

5. Шумило Н. Під знаком національної самобутності : [монографія] / Н. Шумило. К.: Задруга, 2003. 353 с.

6. Донцов Д. Ідеологія чинного націоналізму [Електронний ресурс]. Режим доступу до вид.: http://dontsov-nic.org.ua/files/img/dontsov

7. Донцов Д. Літературна есеїстика: [монографія] / Д. Донцов. Дрогобич : Відродження, 2010. 688 с.

8. Донцов Д. Поетка українського Рісорджіменту (Леся Українка) / Д. Донцов // Українське слово: У 3 т. К. : Рось, 1994. Т. 1. С. 149-183.

9. Донцов Д. Леся Українка / Д. Донцов // Літературно-науковий вісник. 1918. № 12. С. $13-24$.

10. Руснак I. Є. Художня модифікація національної історіософії у прозі Уласа Самчука : автореф. дис. ... д-ра філолог. наук : 10.01.01 / Ірина Євгенівна Руснак. К., 2007. $36 \mathrm{c}$. 


\title{
THE ARTICLE EXAMINES THE IDEA OF STATEHOOD AS A CONCEPTUAL BASIS OF PUBLICISM OF DMITRY DONTSOV
}

\author{
Viktoriia Kolkutina \\ National University «Odesa Law Academy» \\ st. Fontanska road, 23, 65009, Odesa, Ukraine \\ e-mail: kolkutinav@ukr.net \\ https://orcid.org/0000-0002-3823-8415
}

The article examines the idea of statehood as a conceptual basis of publicism of Dmitry Dontsov. The essence of the concept of the Ukrainian national idea as a core and the basis of the idea of statehood in the publicism of D. Dontsov is comprehended in details. The most expressive and meaningful ideas are grounded in articles about Lesia Ukrainka, written by Dontsov. The concept of state literature in his reception was published. It was proved that the process of nation-building in Ukraine was based on the basis of socio-political, historical, social, cultural and personal factors, but its constructive impulses were the mentally weak-willed and twoway psychology of the Ukrainian movement and the ideological exhaustion and non-viability of existing of political doctrines of that time (liberalism, socialism, national-democracy, etc.). The resistance to this mental complexes and ideological stereotypes could be given only by renewed, regenerative leadership based on sacrificial patriotism, the responsibility of the individual for the fate of the nation, sacrifice in the name of freedom and independence, raising the interests of the public over their own, irrationalism, unity around the nation-protective idea directed at the state self-affirmation in the conditions of survival of the dependent nation. Although the publisher expressed ideological thoughts, postulates, tendencies of his time, but proceeded from the specific Ukrainian realities, needs, demands and requests, he shaped and showed the ways of nation-building and nation-statement, without which a nation couln't not exist and survive. It was found out that D. Dontsov's world outlook as a literary publicist on the reflection of the Ukrainian national idea in the work of Ukrainian writers was based on patriotism, active national consciousness and imperative of state independence. In the basis of consolidation of nation, the researcher laid the natural process of evolution of the individual's national consciousness, resulting in a high level of self-development and self-perfection. The spiritual need of person involves the attraction to active life-affirmation, movement, individual and strong-willed recognition.

Key words: Dmitry Dontsov, idea of statehood, national idea, publicism, Ukrainian classical writers. 